ISSN 1997-342X (Online), ISSN 1991-8631 (Print)

Original Paper http://ajol.info/index.php/ijbcs http://indexmedicus.afro.who.int

\title{
Assessment of nutritional resources quality from honeybees (Apis mellifera adansonii, L. 1758: Hymenoptera, Apidae) in three beekeeping sites of the Democratic Republic of Congo
}

\author{
Boniface POSHO NDOLA ${ }^{1,2 *}$, Paul MALUMBA ${ }^{3}$, Bernard WATHELET ${ }^{4}$, \\ Eric HAUBRUGE ${ }^{1}$, Frederic FRANCIS ${ }^{1}$ and Bach Kim NGUYEN ${ }^{1}$
}

\author{
${ }^{1}$ Unit of Functional and Evolutionary Entomology, University of Liège, Gembloux Agro-Bio Tech; \\ 2 Passages des déportés, 5030 Gembloux, Belgium. \\ ${ }^{2}$ Institut Facultaire des Sciences Agronomiques de Yangambi, B.P 1232 Kisangani, R.D.C. \\ ${ }^{3}$ Department of Agro-Industrial Chemistry, University of Kinshasa, BP 127 Kinshasa, DRC. \\ ${ }^{4}$ Unit of Biological and Industrial Chemistry, University of Liège, Gembloux Agro-Bio Tech; 2 Passages des \\ déportés 5030 Gembloux, Belgium. \\ *Corresponding author; E-mail: poshoboni@yahoo.fr; entomologie.gembloux@ulg.ac.be \\ Tel: +32 (0) 81622287, Fax: +32 (0) 81622287
}

\begin{abstract}
Food products from honeybees are commonly used in Africa as in other parts of the world. The composition of bee related food is important for consumers but also to illustrate the feeding quality for the bees. The present study was aimed at assessing the quality of bee bread and honeys for the survival of $A$. mellifera adansonii, L. 1758 in the DRC. Several environments were selected, namely a rainforest in Kisangani, a savannah in Kavwaya and a restored forest in Mampu. Bee breads were assessed according to their richness in proteins and essential amino acids. Honeys were evaluated considering the water content, the sugar rates, the amount of 5-(hydroxymethyl)-2-furaldehyde (HMF), the acidity ( $\mathrm{pH}$ ) and conductivity. The average content of protein from pollens collected in the DRC was $14.11 \pm 5.27 \%$. The protein content was low compared with the food needs of bees (and to the European breeds). No significant difference was observed between Kisangani, Mampu and Kavwaya in terms of protein content of beebread $(\mathrm{P} \geq 0.05)$. The concentrations of ten essential amino acids for bees were within the optimum range of food needs for honeybees (set for European bee races). Beebreads collected in the rainforest of Kisangani were significantly richer in isoleucine, leucine, valine, arginine, lysine and phenylalanine than those from the savannah of Kavwaya. However, beebreads harvested in Kisangani were not significantly different from those from the replanted Mampu forest. The analysis of honey samples revealed that the Congolese honeys had good nutritional quality for bees. Indeed, reducing sugar content of the collected samples ranged from 63.40 to $73.80 \%$, the content of sucrose ranged from 0.30 to $1.90 \%$, the content of water varied from 16.80 to $22.00 \%$, the $\mathrm{pH}$ of the analyzed honey samples ranged from 4.22 to 4.53 . The average of the electrical conductivity was $47.74 \pm 13.93 \mu \mathrm{S} / \mathrm{cm}$ and the concentration of HMF varied from 1.75 to $31.38 \mathrm{mg} \mathrm{HMF} / \mathrm{kg}$ of honey. The honeys collected in the rainforest of Kisangani were significantly richer in minerals and moisture than those
\end{abstract}


from the savannah of Kavwaya $(\mathrm{P}<0.05)$. However, the honeys collected in the last savannah were richer in sucrose and HMF than those collected in the Kisangani rainforest and the restored forest of Mampu $(\mathrm{P}<0.05)$. These results would only be applied for the time at which the samples were collected (January-February) but are an interesting data set for further use of bee related product in DRC.

(C) 2017 International Formulae Group. All rights reserved.

Keywords: Apis mellifera adansonii, honey, bee bread, quality, nutrition, bee ecology, DRC.

\section{INTRODUCTION}

Various multifactorial studies emerged and cited pesticides, diseases, climate change, pollutants, and reduction of nutritional resource quality among others, as probable causes for the decline in honeybee populations (Haubruge et al., 2006). The physicochemical qualities of the nutritional resources stored by bees are considered as one of the most important factor that may depend on their ecosystem and that largely influence the bee population dynamics (Estevinho et al., 2011). Assessment of the nutritional resource quality of honeybees is one of the first exploratory studies of the survival of honeybees ( $A$. mellifera adansonii, L.) in DRC. The quality of beebreads and honeys is the best indicator for determining the health of honeybees in the Congolese ecosystems (DRC).

According to the chemical characteristics of flowering plants present in the bee ecosystem and their environmental parameters, resources stored by bees in their hives may vary, as they are required to have a long-standing relationship with angiosperms present in the ecosystems. Understanding the causes of parallel declines of bees and their host plants requires identifying the various components that make bee-flower interactions both complex and fragile, the extent of their mutual dependence, and the signals that mediate their interactions (Dötterl and Vereecken, 2010). Indeed, according to their age and life cycle, bees have different dietary needs, which may change with the seasons as well as with foraging activity. To meet these dietary needs, nectar and pollen are the two most important resources stored by bees inside their hives (Dibos, 2010). Depending on the plant species from which they are harvested, nectar and pollen may have chemical compositions that can influence both the bee's health and the quality of honey recovered as food for humans.

In the hive, the sugars used are mainly produced from the nectar or honeydew of aphids, which bees collect, transform, and combine with their own specific substances, before storing them and leaving them to ripen in honeycombs. A bee harvests around $40 \mathrm{mg}$ of nectar, which will provide $10 \mathrm{mg}$ of honey. The annual need of honey for a bee normal colony is from 160 to $180 \mathrm{~kg}$ of honey (Alleaume, 2012). The chemical composition of honey varies depending on the floral origin, the apiary climate, the soil, the race of bees and the physiological state of the colonies (Viuda-Martos et al., 2008; Heil, 2011). Pollen is the main source of several essential nutrients for bees. It is a major source of proteins, minerals, lipids and vitamins (Dibos, 2010). These proteins and amino acids are required for the growth of larvae and young bees, and are involved in the development of bee hypopharyngeal glands. Each year, bees of a normal colony harvest around $40 \mathrm{~kg}$ of 
pollen and a worker needs 160 to $180 \mathrm{mg}$ of pollen during his life (Keller et al., 2005). The chemical composition of pollen also depends on the pollen source and the sampling time (Roulston et al., 2000). As stated by Nogueira et al. (2012), beebreads or bee pollen, commonly designated as "the life-giving dust", result from the agglutination of flower pollen, nectar or honey and bees' salivary substances.

The objectives of the present study was firstly to determine the existing link between the environment and the quality of food resources for honeybees in DRC and secondly to assess the nutritional resources quality of honeybees (honey and bee bread) in the DRC. To assess both the influence of ecosystem variability on bee health and the beekeeping potentiality of an area, chemical characterisation of resources stored by bees in their hives may be used as one of the objective criteria. To assess the influence of ecosystem on nutritional resource stored by honeybees and to promote beekeeping in the DRC, it is crucial to determine the quality of honeys and pollens, which are excellent nutritional resources of bees and the major products that ensure the profitability of beekeeping. The Democratic Republic of Congo which straddles the equator is divided into several geographical regions which are heterogeneous in terms of climate, vegetation and soil. Depending on geographical regions, there are features which may influence the quality of nutritional resources of honeybees.

\section{MATERIALS AND METHODS}

Areas of study and sample analysed

There are several beekeeping areas in the DRC. In this study, samples harvested in three beekeeping areas of DRC were analysed (Figure 1). These include Kisangani, Mampu and Kavwaya. These three beekeeping areas were selected because they differ in terms of forest and climate. Their ecological differences may influence the quality of pollen and honey in regions (Estevinho et al., 2011)

Kisangani, an area located in the Eastern region of DRC with the geographical coordinates $25^{\circ} 11^{\prime} \mathrm{E}$ longitude, $0^{\circ} 33^{\prime} \mathrm{N}$ latitude and $390-410 \mathrm{~m}$ altitude, is dominated by rainforest and a hot and humid tropical climate corresponding to $\boldsymbol{A f}$ of Köppen classification (Ngongo, 2006).

Mampu, an area founded in the plateau Batéké at the western part of DRC on geographical coordinates $16^{\circ} 17^{\prime} 51^{\prime \prime} \mathrm{E}$ longitude, $04^{\circ} 18^{\prime} 52^{\prime \prime} \mathrm{S}$ latitude and $720 \mathrm{~m}$ altitude, is dominated by a replanted forest of Acacia and Eucalyptus, with a tropical climate corresponding to $A \boldsymbol{w} 4$ of Köppen classification, characterised by a pronounced dry season which runs from May to September.

Kavwaya, an area located in the western region of Bas-Congo, at the geographical coordinates $15^{\circ} 06^{\prime} \mathrm{E}$ longitude, $5^{\circ} 13^{\prime} \mathrm{S}$ latitude and $525 \mathrm{~m}$ altitude, is a grassland savannah with some forest galleries, and a tropical climate corresponding to $A w 4$ of Köppen classification, which is characterized by a pronounced dry season which runs from May to September.

\section{Analysis of beebreads}

Analyses were carried out on samples of beebreads collected from 01/02/2009 to $15 / 03 / 2009$ in the three ecological sites. The choice of these dates was motivated by the fact that it corresponds to the period of year at which the Congolese beekeepers plan their activities to harvest honey in the three studied areas. Twenty apiaries distributed in the three 
sites were followed in this study: eight at Kisangani, eight at Mampu and four at Kavwaya (Bas-Congo). Five grams of beebreads were carefully removed from each visited apiary to perform the considered analyses. Beebreads were collected in the honeycombs. Their removal was performed after the agreement of surveyed beekeepers. After collection, the samples were stored in the laboratory at $-20{ }^{\circ} \mathrm{C}$ in a plastic bag appropriately labelled (date, location and reference of hives). After extraction, all the breads from the same apiary were pooled and packaged in Petri dishes at $-20{ }^{\circ} \mathrm{C}$ before analysis. As beebreads are mainly considered a source of protein for bees, their nitrogen content $(\mathrm{N})$ was determined using the standard Kjeldahl procedure and the Crude Protein content was calculated using the factor 6.25. Amino acid composition of beebreads was obtained after hydrolysis under nitrogen with $6 \mathrm{~N} \mathrm{HCl}$ at $110^{\circ} \mathrm{C}$ for $24 \mathrm{~h}$. The analysis of the amino acids in a Stein and Moore High Performance Liquid Chromatography (HPLC, Biochrom 20 Plus, Pharmacia, Cambridge, UK). Norleucine (500 $\mathrm{nM})$ was added as an internal standard. The hydrolysates were injected into a cation-exchange column. The amino acids, separated by elution with suitable buffers of increasing $\mathrm{pH}$, were detected with ninhydrin in a continuous flow photometric analytical system at 570 and at $440 \mathrm{~nm}$ (only for proline) and quantified by references (Sigma) used as calibration standards. Sulphur amino acids (cysteine and methionine) were determined as cysteic acid and methionine sulphone, respectively, by a Biochrom 20 Plus (Pharmacia, Cambridge, UK) amino acid analyzer. Before the acid hydrolysis, a performic oxidation was done.

Tryptophan was determined after alkaline hydrolysis of the proteins and SP
8800 HPLC (Spectra physics, San Jose, CA, USA) analysis at $280 \mathrm{~nm}$, with a XTERRA RP18 (4.6 - $150 \mathrm{~mm} ; 3.5 \mathrm{~lm})$ column. The temperature of the column was kept at $45^{\circ} \mathrm{C}$ and the injection volume was $5 \mu$ l. Flow rate was $1 \mathrm{ml} / \mathrm{min}$ with a mixture of solvent $\mathrm{A}$ (760 $\mathrm{ml}$ of sodium acetate buffer $(0.07 \mathrm{M}) /$ triethanolamine $(0.025 \% \mathrm{v} / \mathrm{v})$ adjusted to $\mathrm{pH} 4.5$ with glacial acetic acid $+40 \mathrm{ml}$ of methanol) and solvent B (acetonitrile containing 0.05\% $(\mathrm{w} / \mathrm{v})$ trifluoroacetic acid). The following gradients (solvent $\mathrm{A} /$ solvent $\mathrm{B} / \mathrm{min}$ ) were used: $0 / 100 / 0 ; 0 / 100 / 10 ; 50 / 50 / 5 ; 50 / 50 / 5$; $0 / 100 / 5 ; 0 / 100 / 5$. Separated tryptophan was quantified by using a-methyl-tryptophan as reference.

\section{Analysis of collected honeys \\ - Harvesting of samples}

Samples of honeys were collected from 01 February to $15^{\text {th }}$ march 2009 from the three sites in DRC. Twenty-two samples were collected in twenty-two apiaries where seven at Kisangani, thirteen at Mampu and two at Kavwaya. These samples were extracted using the craft method and stored at a temperature lower than $15^{\circ} \mathrm{C}$ in pots.

- Analysis of samples

In this study, specific criteria related to the quality of honeys were listed as follows: content of water, content of reducing sugar, content of sucrose, content of 5-(Hydroxy Methyl) 2- furfural (HMF), acidity ( $\mathrm{pH}$ ) and electrical conductivity. Duplicate analysis was performed for each sample. Soluble sugars were quantified via HPLC. Samples were homogenized with water for $24 \mathrm{~h}$ and centrifuged at $2790 \mathrm{~g}$ for $30 \mathrm{~min}$ at $25^{\circ} \mathrm{C}$. The extracts were filtered through $0.45 \mu \mathrm{m}$ Millipore filters and a $25 \mu \mathrm{l}$ sample was injected for current HPLC analysis of sugars. DX500 HPLC system was used with a 250-4 
mm column. Reducing sugars and sucrose were analyzed via a High-Performance Anion Exchange Chromatography fitted with a high performance pulsed amperometric detector (HPAEC-PAD, Dionex). Eluted sugars were quantified by the Dionex ICS3000, using a Carbopac PA-100 $(4 * 250 \mathrm{~mm})$. The nature and concentration of sugars were determined by comparison with controls (external standards) injected at known concentrations (Bogdanov et al., 1997). Three standards were used: glucose (Merck), fructose (Fluka) and sucrose (Aldrich). The mobile phase consisted of sodium hydroxide in concentrations varying from 0 to $500 \mathrm{mM}$ at a flow rate of 1 $\mathrm{ml} / \mathrm{min}$. The injection volume was $20 \mu \mathrm{l}$, and the detection of components was compared to an external standard with a regression factor equal to or greater than 0.999 . The Moisture content of samples was determined by an "Abbe Refractmeter" which was thermostated at $40{ }^{\circ} \mathrm{C}$. The refractive index is an optical measure which varies with the concentration of the analysis and the temperature. Electrical conductivity and $\mathrm{pH}$ were determined, respectively, after reading a conductimeter and a pH-meter (Bogdanov, 2005). The HMF concentration was determined using the HPLC method initiated by Zappalà et al. (2004). Five grams of honeys were diluted in $50 \mathrm{ml}$ of distilled water, filtered through a sieve with a 45 microns diameter mesh, and immediately injected for HPLC. The HPLC tool used was fitted with the Agilent Zorbax (300SB-C18) column maintained at $30{ }^{\circ} \mathrm{C}$ during analysis. For the release of $\mathrm{HMF}$ and $2 \mathrm{~F}$, the elution solvent consisted of $90 \%$ water with $1 \%$ acetic acid and $10 \%$ methanol, with the run isocratic method: $1 \mathrm{ml} /$ minute. The standard HMF 5hydroxymethyl furfural was $98 \%$ (across organics) and calibration lines were established by serial dilutions in distilled water.

\section{Statistical analysis}

The bee products collected from the three RDC locations were compared. For the purpose, statistical analysis was performed using the analysis of variance tools of Minitab software with a significance level of $95 \%$, because the distribution of studied parameters was normal. The normality test of AndersonDarling revealed an abnormal distribution in all five parameters studied to assess the Congolese honeys. Thus, a comparison of medians values between beekeeping sites was performed using the Kruskal-Wallis test.

\section{RESULTS}

\section{Analysis of protein in beebread}

The protein content of recovered beebread is presented in Table 1.

The protein content of recovered beebread varied from 1.66 to $21.91 \%$ with an average of $14.11 \pm 5.27 \%$ (Table 1). Despite their presumable moisture content, pollens from the rainforest of Kisangani were related to the richer beebread in protein content $(16.10 \pm 3.13 \%)$ than that from the savannah of Kavwaya (8.83 $\pm 7.98 \%)$ and the restored forest of Mampu (14.76 $\pm 4.17 \%$ ), (Table 1). When comparing the three studied sites (Table 1), the protein contents of beebread were similar between the rainforest of Kisangani, the savannah of Kavwaya and the restored forest of Mampu $(p \geq 0.05)$.

\section{Amino acid composition of beebreads}

The amino acid compositions of beebread are presented Table 2 and the concentrations of essential aminoacids of beebread are presented Table 3 and Figure 2: 18 amino acids were present in all the samples 
of beebread after hydrolysis. Also, ten essential amino acids (isoleucine, leucine, valine, arginine, lysine, phenylalanine, threonine, histidine, methionine and tryptophan) were present in all collected beebread samples.

When comparing the three studied sites, the beebreads from the rainforest of Kisangani were significantly richer in isoleucine, leucine, valine, arginine, lysine and phenylalanine than those of the savannah of Kavwaya (Table 2).

The restored forest of Mampu and the rainforest of Kisangani showed a similarity in their content for all ten essential amino acids of bees ( $p \geq 0.05)$ (Figure 2 and Table 3 ).

\section{Results of honey analysis}

The mean values of the physicochemical parameters measured in different honey samples are shown in Table 4 and Figure 3. The median values obtained at each site were compared in order to highlight the effect of the characteristics of each ecosystem or site on the qualities of Congolese honeys. Firstly, the content of reducing sugars of various analyzed honey samples ranged from 63.40 to $73.80 \%$, with an average of $68.17 \pm 3.49 \%$. This was within the optimum range $(\geq 65 \%)$ set by CODEX Alimentarius. Secondly, the sucrose content varied between 0.3 and $1.9 \%$ with an average of $1.00 \pm 0.41 \%$. These values are included in the optimum range $(\leq 5 \%)$ (Bogdanov et al., 1999). Then, the content of water in honeys ranged from 16.80 to $22.00 \%$ with an average of $18.80 \pm 1.74 \%$, which is within the recommended thresholds $(\leq 21 \%)$ of CODEX Alimentarius.. Also, the $\mathrm{pH}$ of the honey samples analyzed ranged from 4.22 to 4.53 , with an average of $4.36 \pm 0.10$, which is within the range of 3.5 to 5.5 (Bogdanov, 2005). The average electrical conductivity obtained for all the 22 samples collected in the DRC was $47.74 \pm 13.93 \mathrm{mS} / \mathrm{cm}$, which was well within the optimal range of Codex Alimentarius ( $\leq$ $0.8 \mathrm{mS} / \mathrm{cm}$ ) (Bagdanov et al., 2005). The average concentration of HMF in honey samples ranged between 1.75 and $31.38 \mathrm{mg}$ $\mathrm{HMF} / \mathrm{kg}$ of honey, with an overall average of $13.97 \pm 8.40 \mathrm{mg} / \mathrm{kg}$; this was in the range of 0 $80 \mathrm{mg} / \mathrm{kg}$ set by CODEX Alimentarius (Zappalà et al., 2004). Finally, the concentration of HMF of the 22 samples ranged from 1.75 to $31.38 \mathrm{mg} \mathrm{HMF} / \mathrm{kg}$ of honey, with an overall average of $13.97 \pm 8.40$ $\mathrm{mg} \mathrm{HMF} / \mathrm{kg}$ of honey. Between the studied sites, the honeys collected in the rainforest of Kisangani were richer in reducing sugar (70.87\%) and humidity (21.29\%) than those collected in the savannah of Kavwaya (reducing sugars $=66.1 \%$, water $=$ 16.8\%)(Figure 3 and Table 4). Statistically, the content of reducing sugars in honeys was similar between the rainforest of Kisangani, the savannah of Kavwaya and the restored forest of Mampu ( $p \geq 0.05$ ). The electrical conductivity of Kisangani honeys (39.24 \pm 0.54) was larger than those of the samples from Mampu and Kavwaya ( $\mathrm{C}=36.45$ $\mathrm{mS} / \mathrm{cm}$ ) (Figure 3 and Table 4). Nonetheless, samples of honeys collected in the savannah of Kavwaya were richer in HMF and in sucrose (17.11 mg HMF/kg honey and 1.90\% sucrose) than those of the rainforest of Kisangani (4.21 mg HMF/kg honey and $0.53 \%$ sucrose) and the restored forest of Mampu (Figure 3 and Table 4). 


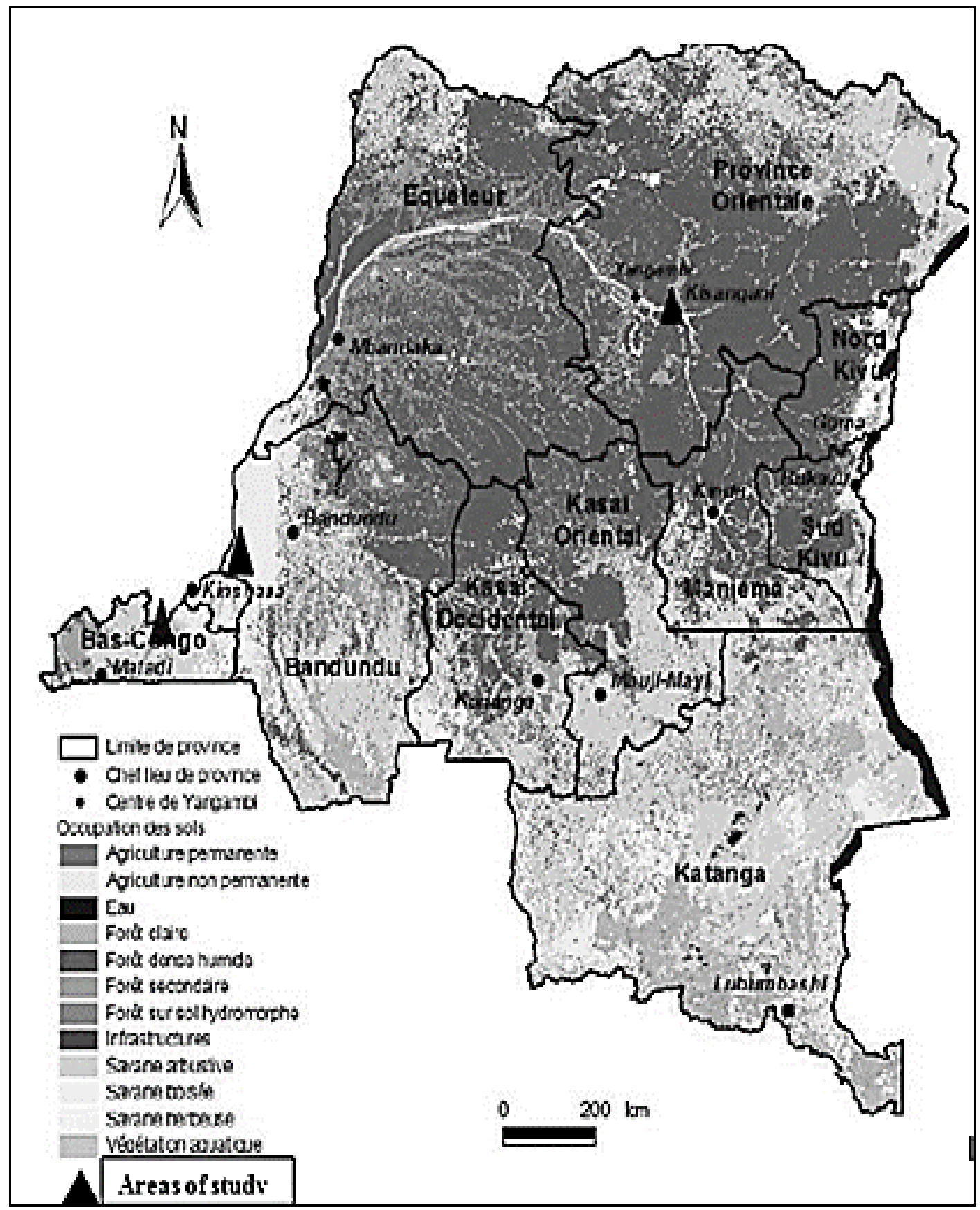

Figure 1: DRC: Land Use Map. The legend shows the main plant formations and areas of study (Boyemba, 2011). 
Table 1: Results of analysis of protein content (in dry basis) in samples of Congolese beebread.

\begin{tabular}{lccccc}
\hline \multirow{2}{*}{ Sites } & & & \multicolumn{3}{c}{ Concentration of protein (\%) } \\
& $\mathbf{N}$ & Water (\%) & Average & Maximum & Minimum \\
\cline { 4 - 5 } & & & & & \\
\hline Kavwaya & 4 & $23,82 \pm 1,53$ & $8.83 \pm 7.98 \mathrm{a}$ & 15.89 & 1.66 \\
Kisangani & 8 & $26,31 \pm 2,44$ & $16.10 \pm 3.13 \mathrm{a}$ & 20.00 & 11.31 \\
Mampu & 8 & $23,70 \pm 1,07$ & $14.76 \pm 4.17 \mathrm{a}$ & 21.91 & 9.20 \\
Average & & $24,77 \pm 2,16$ & $14.11 \pm 5.27$ & 21.91 & 1.66 \\
\hline
\end{tabular}

The letters $(a, b)$ represent which bee breads are different (or similar) by statistical test with a significance of $\mathrm{p}=0.05$

Table 2: Composition and concentrations of amino acids in beebreads

\begin{tabular}{|c|c|c|c|c|}
\hline \multicolumn{5}{|c|}{ Concentration of amino acids (\%) } \\
\hline Amino acids & Kisangani & Mampu & Kavwaya & Average \\
\hline Isoleucin (Ile) & $0.84 \pm 0.17 \mathrm{a}$ & $0.81 \pm 0.20 \mathrm{a}$ & $0.48 \pm 0.22 b$ & $0.76 \pm 0.23$ \\
\hline Leucin (Leu) & $1.30 \pm 0.25 \mathrm{a}$ & $1.24 \pm 0.30 \mathrm{a}$ & $0.76 \pm 0.33 b$ & $1.17 \pm 0.34$ \\
\hline Valin (Val) & $1.11 \pm 0.18 \mathrm{a}$ & $1.08 \pm 0.23 \mathrm{a}$ & $0.70 \pm 0.28 b$ & $1,02 \pm 0.27$ \\
\hline Arginin (Arg) & $1.00 \pm 0.22 \mathrm{a}$ & $0.91 \pm 0.25 \mathrm{a}$ & $0.48 \pm 0.14 b$ & $0.86 \pm 0.29$ \\
\hline Lysin (Lys) & $1.33 \pm 0.26 \mathrm{a}$ & $1.26 \pm 0.26 \mathrm{a}$ & $0.72 \pm 0.20 \mathrm{~b}$ & $1.18 \pm 0.34$ \\
\hline Phenylalanin (phe) & $0.79 \pm 0.18 \mathrm{a}$ & $0.78 \pm 0.21 \mathrm{a}$ & $0.43 \pm 0.21 b$ & $0.71 \pm 0.24$ \\
\hline Threonin (Thr) & $0.81 \pm 0.16 \mathrm{a}$ & $0.77 \pm 0.18 \mathrm{a}$ & $0.47 \pm 0.21 \mathrm{a}$ & $0.73 \pm 0.21$ \\
\hline Histidin (his) & $0.58 \pm 0.14 \mathrm{a}$ & $0.55 \pm 0.12 \mathrm{a}$ & $0.53 \pm 0.18 \mathrm{a}$ & $0.56 \pm 0.22$ \\
\hline Methionin (met) & $0.26 \pm 0.02 \mathrm{a}$ & $0.28 \pm 0.08 \mathrm{a}$ & $0.27 \pm 0.01 \mathrm{a}$ & $0.27 \pm 0.05$ \\
\hline Tryptophan (TRP) & $0.21 \pm 0.01 \mathrm{a}$ & $0.21 \pm 0.06 \mathrm{a}$ & $0.24 \pm 0.04 \mathrm{a}$ & $0.22 \pm 0.04$ \\
\hline Aspartic acid & $1.82 \pm 0.36 \mathrm{a}$ & $1.82 \pm 0.36 \mathrm{a}$ & $1.09 \pm 0.45 b$ & $1.67 \pm 0.47$ \\
\hline Serin & $0.94 \pm 0.17 \mathrm{a}$ & $0.89 \pm 0.21 \mathrm{a}$ & $0.56 \pm 0.24 b$ & $0.85 \pm 0.24$ \\
\hline Glutamic acid & $1.91 \pm 0.41 \mathrm{a}$ & $1.84 \pm 0.41 \mathrm{a}$ & $1.14 \pm 0.45 b$ & $1.73 \pm 0.50$ \\
\hline Prolin & $0.95 \pm 0.13 \mathrm{a}$ & $1.04 \pm 0.17 \mathrm{a}$ & $0.61 \pm 0.27 b$ & $0.92 \pm 0.24$ \\
\hline Glycin & $0.82 \pm 0.15 \mathrm{a}$ & $0.77 \pm 0.18 \mathrm{a}$ & $0.48 \pm 0.21 b$ & $0.73 \pm 0.21$ \\
\hline Alanin & $0.97 \pm 0.16 \mathrm{a}$ & $0.90 \pm 0.21 \mathrm{ab}$ & $0.59 \pm 0.26 b$ & $0.87 \pm 0.24$ \\
\hline Tyrosin & $0.54 \pm 0.13 \mathrm{a}$ & $0.50 \pm 0.15 \mathrm{ab}$ & $0.28 \pm 0.15 b$ & $0.47 \pm 0.16$ \\
\hline Cystein & $0.22 \pm 0.01 \mathrm{a}$ & $0.23 \pm 0.06 \mathrm{a}$ & $0.23 \pm 0.01 \mathrm{a}$ & $0.23 \pm 0.04$ \\
\hline
\end{tabular}


Table 3: Comparison of concentrations of essential aminoacids obtained after hydrolysis and the recommended dosage to meet optimal development of bees in Europe (De Groot, 1953).

\begin{tabular}{|c|c|c|c|c|}
\hline $\begin{array}{l}\text { Essential amino } \\
\text { acids }\end{array}$ & $\begin{array}{c}\text { Kisangani obtained } \\
\text { doses }(\mathrm{g} / 16 \mathrm{gN})\end{array}$ & $\begin{array}{c}\text { Mampu } \\
\text { obtained doses } \\
(\mathrm{g} / 16 \mathrm{~g} \mathbf{N})\end{array}$ & $\begin{array}{c}\text { Kavwaya } \\
\text { obtained doses } \\
(\mathrm{g} / \mathbf{1 6} \mathrm{g} \mathbf{N})\end{array}$ & $\begin{array}{l}\text { Minimum doses } \\
\qquad(\mathrm{g} / 16 \mathrm{~g} \mathbf{N}) \\
\text { according to de } \\
\text { Groot (1953) }\end{array}$ \\
\hline Isoleucin & 5.22 & 5.49 & 5.44 & 4 \\
\hline Leucin & 8.07 & 8.4 & 8.61 & 4.5 \\
\hline Valin & 6.89 & 7.32 & 7.93 & 4 \\
\hline Arginin & 6.21 & 6.17 & 5.44 & 3 \\
\hline Lysin & 8.29 & 8.54 & 8.15 & 3 \\
\hline Phenylalanin & 4.91 & 5.28 & 4.87 & 1.5 \\
\hline Threonin & 5.03 & 5.21 & 5.32 & 3 \\
\hline Histidin & 3.6 & 3.73 & 6 & 1.5 \\
\hline Methionin & 1.61 & 1.9 & 3.06 & 1.5 \\
\hline Tryptophan & 1.3 & 1.42 & 2.72 & 1 \\
\hline
\end{tabular}

(g/ 16 g N): concentration of amino acid expressed by g/ $16 \mathrm{~g} \mathrm{~N} ; \quad \%$ A: Percentage of amino acid;

$\%$ P: percentage of protein; $\quad \mathrm{N}$ : Azote.
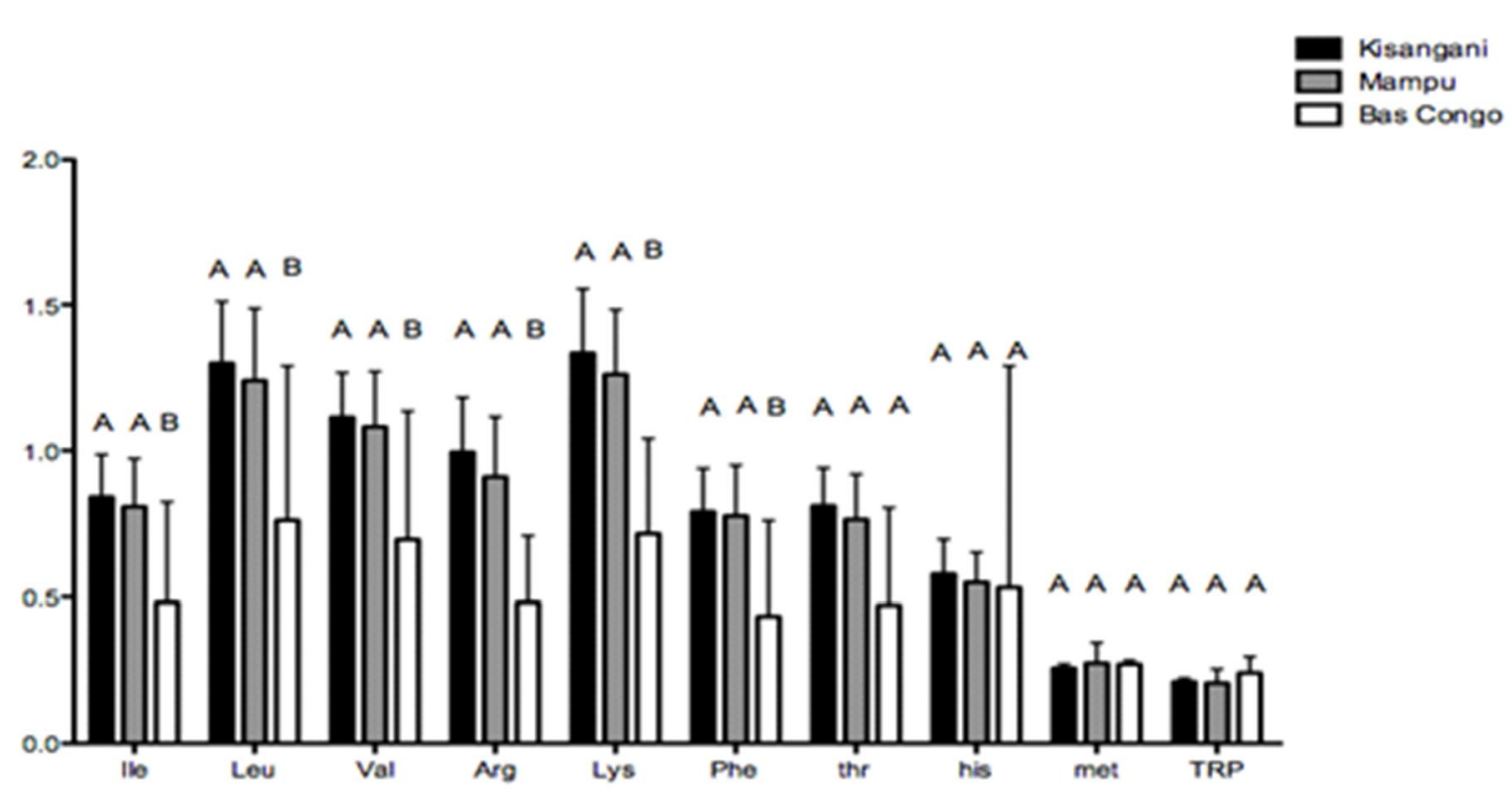

Figure 2: Distribution of values contains essential amino acids in pollen (\%) on the sites. Isoleucin (Ile), Leucin (Leu), Valin (Val), Arginin (Arg), Lysin (Lys), Phenylalanin (phe), Threonin (Thr), Histidin (his), Methionin (met) andTryptophan (TRP). The letters (A, B) represent which bee breads are different (or similar) by statistical test with a significance of $\mathrm{p}=0.05$. 


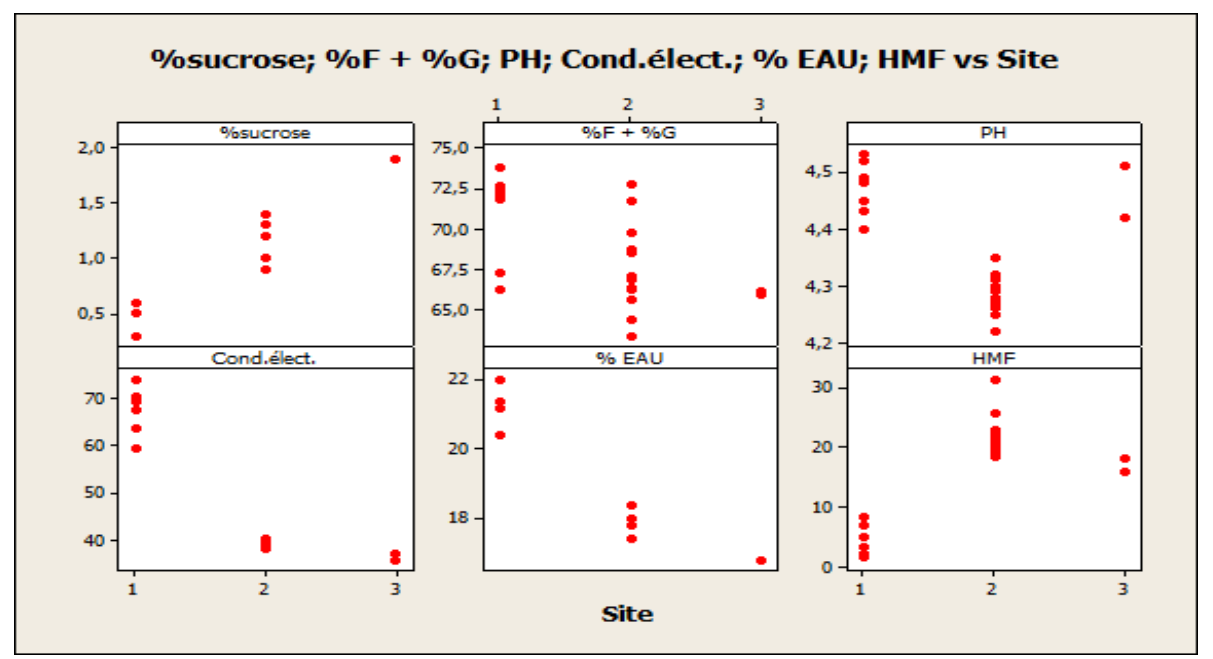

Figure 3: Distribution of values of six physicochemical parameters of honeys based on the sites. 1: Kisangani, 2: Mampu, 3: Kavwaya, F: fructose and G: glucose.

Table 4 : Mean values of physicochemical parameters of honey samples from the DRC.

\begin{tabular}{|c|c|c|c|c|c|c|}
\hline Parameters & Sites & Average & Minimum & Maximum & $\begin{array}{c}\text { Thresholds of } \\
\text { CODEX }\end{array}$ & P-Value \\
\hline \multirow{4}{*}{ \% sucrose } & Kisangani & $0.53 \pm 0.11$ & 0.30 & 0.60 & \multirow{4}{*}{$\leq 5.00$} & \multirow{4}{*}{$\mathbf{P}<0.005$} \\
\hline & Mampu & $1.11 \pm 0.18$ & 0.90 & 1.40 & & \\
\hline & Kavwaya & $1.85 \pm 0.07$ & 1.80 & 1.90 & & \\
\hline & Average & $1.00 \pm 0.41$ & 0.30 & 1.90 & & \\
\hline \multirow{4}{*}{$\begin{array}{l}\text { \% Reducing } \\
\text { sugars }\end{array}$} & Kisangani & $70.87 \pm 2.87$ & 66.30 & 73.80 & \multirow{4}{*}{$\geq 65.00$} & \multirow{4}{*}{0.110} \\
\hline & Mampu & $67.85 \pm 3.32$ & 63.40 & 72.70 & & \\
\hline & Kavwaya & $66.10 \pm 0.28$ & 66.00 & 66.20 & & \\
\hline & Average & $68.17 \pm 3.49$ & 63.40 & 73.80 & & \\
\hline \multirow{4}{*}{$\mathbf{P h}$} & Kisangani & $4.47 \pm 0.05$ & 4.40 & 4.53 & \multirow{4}{*}{$3.50-5.50$} & \multirow{4}{*}{$\mathbf{P}<0.005$} \\
\hline & Mampu & $4.28 \pm 0.03$ & 4.22 & 4.35 & & \\
\hline & Kavwaya & $4.47 \pm 0.06$ & 4.42 & 4.51 & & \\
\hline & Average & $4.36 \pm 0.10$ & 4.22 & 4.53 & & \\
\hline \multirow{4}{*}{$\begin{array}{l}\text { Electric } \\
\text { conductivity }\end{array}$} & Kisangani & $67.97 \pm 4.74$ & 59.80 & 74.10 & \multirow{4}{*}{$\leq 800 \mu \mathrm{S} / \mathrm{cm}$} & \multirow{4}{*}{$\mathbf{P}<0.005$} \\
\hline & Mampu & $39.24 \pm 0.54$ & 38.10 & 40.40 & & \\
\hline & Kavwaya & $36.45 \pm 0.78$ & 35.90 & 37.00 & & \\
\hline & Average & $47.74 \pm 13.93$ & 35.90 & 74.10 & & \\
\hline \multirow{4}{*}{$\%$ water } & Kisangani & $21.29 \pm 0.47$ & 20.40 & 22.00 & \multirow{4}{*}{$\leq 21.00$} & \multirow{4}{*}{$\mathbf{P}<0.005$} \\
\hline & Mampu & $17.84 \pm 0.34$ & 17.40 & 18.40 & & \\
\hline & Kavwaya & $16.80 \pm 0.00$ & 16.80 & 16.80 & & \\
\hline & Average & $18.80 \pm 1.74$ & 16.80 & 22.00 & & \\
\hline \multirow{4}{*}{$\begin{array}{l}\text { HMF } \\
(\mathrm{mg} / \mathrm{kg})\end{array}$} & Kisangani & $4.21 \pm 1.81$ & 1.75 & 8.37 & \multirow{4}{*}{$<80.00 \mathrm{mg} / \mathrm{kg}$} & \multirow{4}{*}{$\mathbf{P}<0.005$} \\
\hline & Mampu & $22.17 \pm 3.63$ & 18.63 & 31.38 & & \\
\hline & Kavwaya & $17.11 \pm 0.95$ & 15.94 & 18.27 & & \\
\hline & Average & $13.97 \pm 8.40$ & 1.75 & 31.38 & & \\
\hline
\end{tabular}




\section{DISCUSSION}

\section{Analysis of protein in beebread}

The results on the protein content of recovered beebread were within the range of 2.3 to $61.7 \%$ described by Keller et al. (2005). Analyzing eight beebreads from Spain and Portugal, Nogeuira et al. (2012) observed a crude protein content within the range of 8 to $25 \%$. Protein contents in stored beebread analyzed seemed slightly lower than that observed in commercial pollens by Estevinho et al. (2011) which ranged between 24.23\% and $34.18 \%$. These differences can be explained by the fact that pollen stored in the hive, as analyzed in the present study, resulted from the agglutination of flower pollen, nectar or honey and bees' salivary substances. The presence of these foreign materials in beebread could induce a slight decrease in its protein concentration. The average protein content of pollen recovered is lower than the $20 \%$ required to ensure the optimal development of bees in Europe (Kleinschmidt, 1986). According to the latter, in optimal conditions in Europe, one colony of bee requires pollens with a protein content equivalent to $20 \%$. During the honey age, the needs of the colony would increase and would range from $25 \%$ to $30 \%$ of protein when the honey ages are intense. Unfortunately, there are no previous studies which have focused on the feeding behavior of $A$. mellifera adansoni, which is a smaller race and is different to Europeans ones (Winston, 1993). It seems like forest ecosystems, which are characterised by high relative environment humidity and high average temperatures, provide pollens with higher protein contents than savannah ecosystems, which are drier (AlmeidaMuradian et al., 2005). Differences in the protein richness of the pollen collected would also depend on the botanical composition of the analyzed beebreads (Roulston et al., 2000; Estevinho et al., 2011).

\section{Amino acid composition of beebreads}

The results on amino acid compositions of beebread confirmed the conclusions of Wille et al. (1985), according to which there were no qualitative differences in the amino acid composition of the various selected pollens and most of them contained all ten amino acids that are essential for bees. Furthermore, when we considered the score of each amino acid compared with a standard beebread composition, the concentrations of the ten essential amino acids observed in the present study were in the range of amino acid content recommended by De Groot (1953) for the safe development of honeybees in Europe. Given that the majority of bee livestock in the DRC is formed exclusively of the species $A$. mellifera adansonii, L., which has a different morphology and feeding behavior the european species, it is not possible to make an accurate modeling between the concentrations of essential amino acids in pollen and the development of bees, because no previous studies that have been focused on assessment of the essential amino acids required for the safe development of $A$. mellifera adansonii, L. exist. The differences in the concentrations of isoleucine, leucine, valine, arginine, lysine and phenylalanine between the restored forest and the savannah of Kavwaya would depend on the botanical composition of the analysed beebreads (Wille et al., 1985; Roulston et al., 
2000; Estevinho et al., 2011). The similarity in the amino acids richness of the beebreads between the restored forest and the rainforest reveals the positive impact of reforestation on improving the nutritional resource quality of honeybees.

\section{Honey analysis}

The analyzed samples of Congolese honeys contain honey of good qualities stored by bees for their consumption. Considering the CODEX Alimentarius standards (1998) for the physicochemical properties of honey, it can be concluded that the twenty-two Congolese samples of honeys corresponded to the six criteria of quality established by the International Commission of honey. However, special attention should be given to honeys from Kisangani. The average humidity of that was above $20 \%$ (Bagdanov et al., 1999). Between the studied sites, the honeys collected in the rainforest of Kisangani were richer in reducing sugar and humidity than those collected in the savannah of Kavwaya. This could involve some difficulties in their conservation, since some microbial fermentation can appear when honey has higher moisture content. The electrical conductivity of Kisangani honeys was larger than those of the samples from Mampu and Kavwaya This electrical conductivity predominantly depends on the mineral content of honey (Andrede et al., 1999). Nonetheless, samples of honeys collected in the savannah of Kavwaya were richer in HMF and in sucrose than those of the rainforest of Kisangani and the restored forest of Mampu (These differences are due to the botanical composition of honeys and the climates that predominate in each of the studied areas. In terms of climate, Kisangani is located $\left(0^{\circ} 33^{\prime} \mathrm{N}\right)$ closer to the equator than Mampu (4¹8'52"S) and Kavwaya (5¹3'S). Therefore, it is warmer in Kisangani than at Kavwaya and Mampu. According to Lichtenberg-Kraag (2012), the rate of degradation of sucrose present in the honey directly depends on the storage temperature of the honey. The results of Lichtenberg-Kraag (2012) also revealed that the rate of degradation of sucrose showed a positive correlation with the invertase activity, $\mathrm{pH}$, electrical conductivity, glucose content and fructose content.

\section{Conclusion}

The objective of the present study was to assess the quality of beebread and honeys in DRC. In addition to this objective, we determined the influence of environmental factors (forest and climate) on the quality of food resources for bees. We used the criteria of wealth in proteins and essential amino acids for assessing the quality of bee bread collected by bees, while the honey qualities were assessed on the basis of six quality criteria established by CODEX Alimentarius.

Our investigations have led to conclude that:

- The average of content of protein in pollens was lower than the $20 \%$ required ensuring optimal development of bees in Europe. Given these results, we do not recommend Congolese beekeepers using European species of bees in their apiaries. Statistically, this study showed that the protein content of beebread was similar between the rainforest of Kisangani, the savannah of Kavwaya and the restored forest of Mampu. 
- All of the pollen samples collected from three beekeeping sites in the DRC have a similar amino acid composition and all of the samples analyzed contain 10 essential amino acids in adequate doses to ensure the optimal development of European bees. Statistically, the forest of Kisangani offered bee breads that were richer in essential amino acids than the savannah of Kavwaya, except for tryptophan, methionine, histidine and threonine. However, the restored forest of Mampu and the rainforest of Kisangani showed similarities in their doses of all ten essential amino acids for bees. This similarity between Kisangani and Mampu clearly shows that the reforestation of the forest has a positive effect on the quality of food resources of bees.

All the honey samples comply to the six quality criteria established by CODEX Alimentarius This confirms the hypothesis that the quality of energy resource of honeybees is not a constraint for beekeeping in DRC. However, honeys from the forest region of Kisangani were richer in minerals and reducing sugars than those of the savannah of Kavwaya. In contrast, the samples of honeys collected from the savannah of Kavwaya were richer in HMF and in sucrose than those of the rainforest of Kisangani.

In the current context where there is no published evidence for the correlation between the quality of food resources (pollen and honey) and the optimal development of bees in the DRC, it is less easy to draw a definitive conclusion on the nutritional quality of bees in the DRC. To get an overall idea of the annual food availability for bees in all the ecosystems of the DRC, we suggest that further studies in this area be spread over time and space by integrating the physiology of plants, variations of the climatic seasons and biology of bees.

\section{COMPETING INTERESTS}

The authors declare that they have no competing interests.

\section{AUTHORS' CONTRIBUTIONS}

BPN, is the main actor of this research. He participated in the development of the protocol, the execution of the protocol, the analysis and interpretation of the results and the writing of the manuscript. $\mathrm{EH}$, the promoter of this research, contributed to the development of the initial protocol, the execution of the protocol of this work, the analysis and interpretation of the results. BKN, Co-Proponent of this work, contributed to the development of the initial protocol, the execution of the protocol of this work, the analysis and interpretation of the results. FF, Head of Functional and Evolutionary Entomology at the University of LiègeGembloux Agro-BioTech, is the person who oversaw all the research work from the development of the research protocol to the analysis and interpretation of the results. BW, Head of the Laboratory of Biological chemistry at the University of Liège, Gembloux Agro-Bio Tech for his contribution to the chemical analysis and commentary on the manuscript. PM of the University of Kinshasa, agreed to devote his time and energy to improve the present manuscript.

\section{ACKNOWLEDGMENTS}

We thank the members of the Laboratory of Biological Chemistry of the 
University of Liège, Gembloux Agro-Bio Tech for their contribution to the chemical analysis and commentary on the manuscript

\section{REFERENCES}

Alleaume C. 2012. Abeille domestique (Apis mellifera, L). Exemple pour l'étude de l'attractivité des plantes cultivées sur les insectes pollinisateurs. Thèse de doctorat, Ecole Nationale Vétérinaire d'Alfort (France), 95p.

Almeida-Muradian LB, Pamplona LC, Coimbra S, Barth OM. 2005. Chemical composition and botanical evaluation of dried bee pollen pellets. Journal of ood Composition and Analysis, 18(1): 105 111. DOI: www.scielo.br/scielo.php? script $=$ sci_arttext\&pid $=\mathrm{S} 0001$

Andrede PB, Amaral MT, Isabel P, Caryalho JCMF, Seabra RM, Proenca Da Cunho A. 1999. Physicochemical attributes and pollen spectrum of portugeuse heather honeys. Food Chemistry, 66: 503-510. DOI: www.scielo.br/scielo.php?script $=$ sci_arttext\&pid=S0101

Bogdanov S. 2005. Miels mono floraux suisses. Ed. Station de recherche agro scope liebefeld. Posieux ALP forum $23.55 \mathrm{p}$.

Bogdanov S, Lüllmann C, Martin P, Von Der Ohe W, Russmann H, Vorwoh G, Persano Oddo L, Sabatini AG, Marcazzan GL, Piro R, Flamini C, Morlot M, Lheritier J, Borneck R, Marioleas P, Tsigouri A, Kerkyliet J, Ortiz A, Ivanov T, D'arcy B, Mossel B, Vit P. 1999. Honey quality, methods of analysis and international regulatory standards, review of the work of the International Honey Commission. Mitt. Lebensm. Hyg. 90108-125. DOI: www.bee-
hexagon.net/files/file/.../AuthenticityRev ue_Internet.pd

Bogdanov S, Martin P, Lüllmann C. 1997. Harmonised methods of the European Honey Commission. Apidologie (Extra issue) 1-59. DOI: www.ihcplatform.net/ihcmethods2009.pdf

Boyemba F. 2011. Ecologie de Pericopsis elata (Harms) Van Meeuwen (Fabaceae), arbre de forêt tropicale africaine à répartition agrégée. Thèse de doctorat: Université Libre de Bruxelles (Belgique). 182p

Codex Alimentarius. 1998. Draft Revised For Honing At Step 6 Of The Codex Procedure. CX 5/10, 2, CL 1998/12-S

De Groot AP. 1953. Protein and amino acid requirements of the honey bee (Apis mellifera L.), physiol. Comp. Oecol. 3: 197-283.

DOI : www.jas.org.pl/pdf/47?filename $=$ jas 48

Dibos C. 2010. Interactions plante pollinisateur. Caractérisation de la qualité du pollen de deux Cucurbitacées durant son ontogenèse, sa présentation et son transport sur le corps de l'abeille domestique. Thèse de doctorat: Université d'Avignon et des pays de Vaucluse (France). 174p

Dötterl S, Vereecken NJ. 2010. The chemical ecology and evolution of beeflowerinteractions: a review and perspectives. Can. J. Zool., 88: 668-697 . DOI: www.nrcresearchpress.com/doi/ abs/10.1139/Z10-031

Estevinho L, Rodrigues S, Pereira A, Feas X. 2011. Portuguese bee pollen: palynological study, nutritional and microbiological evaluation. International Journal of Food Science and Technology, 47: 429-435. DOI: /10.1111/j.1365...2011...x/abstrac 
www.hranomdozdravlja.com/slatkis/file. php?file...pdf

Haubruge E, Nguyen BK, Widart J, Thome JP, Fickers P, Depauw E. 2006. Le dépérissement de l'abeille domestique, Apis mellifera L. 1758 (Hymenoptera: Apidea) : faits et causes probables, Notes Faunistiques de Gembloux, 59(1): 3-21. DOI : $\quad$ www.scielo.org.co/pdf/luaz/ n36/n36a07

Heil M. 2011. Nectar: Generation, regulation and ecological functions. Trends in plant Science, 16: 191-200. DOI: https://www.ncbi.nlm.nih.gov/pubmed/2 1345715

Keller I, Fluri P, Imdorf I. 2005. Le pollen et le développement des colonies chez l'abeille mellifica-première partie. Site web Station de Recherche Agroscope Liebefeld - Posieux ALP - Centre de Recherche Apicole 13p.

Kleinschmidt GJ. 1986. Nutrition for long life bees. Research poper 3.5.7, Queensland Agric. College, Lawes, Queensland. Dep. Of plant protection and the Queensland Beekeepers association. www.nationalbeeunit.com/download Document.cfm?id=267

Lichtenberg - Kraag B. 2012. Saccharose degradation over time in stored honey: influence of time, temperature, enzyme activity and botanical origin. J. Food Nutr. Res., 51: 217-224. DOI: www.vup.sk/en/index.php?mainID $=2 \&$ n $\operatorname{avID}=34$

Nogueira C, Iglesias A, Feas X, Estevinho LM. 2012. Commercial Bee Pollen with Different Geographical Origins: A Comprehensive Approach. Int. J. Mol.
Sci., 13: 11173-11187. DOI: https://www.ncbi.nlm.nih.gov

Ngongo ML, Van Ranst E, Baert G, Kasongo EL, Verdoodt A, Mujinya BB, Mukalay JM. 2009. Guide des sols en R.D. Congo. Tome I : Etude et Gestion. UGent - HoGent - UNILU, 262p

Roulston T, Cane JH. 2000. Pollen nutritional content and digestibility for animals. Plant Systematic and Evolution, 222: 187-209. DOI: https://works.bepress. com/ james_cane/101/

Viuda-Martos M, Rutz-Navajas Y, FernandezLopez J, Perez-Alvarez JA. 2008. Antibacterial activity of different essential oils obtained from spices widely used in Mediterranean diet. International Journal of Food Science \& Technology, 43: 526 - 531. DOI: www.mdpi.com/2076-3921/2/4/384/pdf

Wille H, Wille M, Kilchenmann Y, Imdorf A, Bühlmann G. 1985. Pollenernte und Massenwechsel von drei Apis melliferaVölkern auf demselben Bienenstand in Zwei aufeinanderfolgen-den Jahren. Revue Suisse de Zoologie, 92: 897-914. DOI : www.spmf.fr/enligne/pollen2_f.pdf

Winston ML. 1993. La biologie de l'abeille. Nauwelaerts, Beauvechain. FrisonRoche, Paris ; 276p.

Zappala M, Fallici B, Arena E, Verzera A. 2004. Method for the determination of HMF in honey: a comparison, food control, 16: 273-277. DOI: www.vup.sk/en/ download.php?bulID $=6$. scholar.google.it/citations? user $={ }_{S} C \operatorname{set} P U$ AAAAJ\&hl=it 